\title{
Flushing time of solutes and pollutants in the central Great Barrier Reef lagoon, Australia
}

\author{
Yonghong Wang ${ }^{\mathrm{A}, \mathrm{B}, \mathrm{E}}$, Peter V. Ridd ${ }^{\mathrm{B}}$, Mal L. Heron ${ }^{\mathrm{B}}$, Thomas C. Stieglitz ${ }^{\mathrm{B}, \mathrm{C}}$ \\ and Alan R. Orpin ${ }^{\mathrm{B}, \mathrm{D}}$ \\ ${ }^{A}$ College of Marine Geoscience, Ocean University of China, Qingdao 266003, China. \\ ${ }^{B}$ School of Mathematics, Physics and Information Technology, James Cook University, \\ Townsville, Qld 4811, Australia. \\ ${ }^{C}$ Australian Institute of Marine Science, PMB 3, MC, Townsville, Qld 4810, Australia. \\ D NIWA, Private Bag 14-901, Kilbirnie, Wellington, New Zealand. \\ ${ }^{E}$ Corresponding author. Email: yonghong.wang@jcu.edu.au
}

\begin{abstract}
The flushing time of the central Great Barrier Reef lagoon was determined by using salinity as a tracer and developing both an exchange model and a diffusion model of the shelf exchange processes. Modelling suggests that the cross-shelf diffusion coefficient is approximately constant for the outer half of the lagoon but decays rapidly closer to the coast. The typical outer-shelf diffusion coefficient is $\sim 1400 \mathrm{~m}^{2} \mathrm{~s}^{-1}$, dropping to less than $100 \mathrm{~m}^{2} \mathrm{~s}^{-1}$ close to the coast. Flushing times are around 40 days for water close to the coast and 14 days for water in the offshore reef matrix.
\end{abstract}

Additional keywords: diffusion coefficient, exchange and diffusion model.

\section{Introduction}

The effect of terrestrially derived particulates and solutes and their influences on the ecosystems of the Great Barrier Reef (GBR) has received considerable scientific attention over recent years (Hoegh-Guldberg 1999; Anthony 2000; Haynes et al. 2000a; Baker 2003; Wolanski et al. 2003). These particles and solutes, derived primarily from agricultural activity on the coastal plain, include the direct influence of elevated concentrations of suspended sediment, nutrients (such as nitrogen and phosphorus) and herbicides. The impacts of these particles and solutes can prove difficult to demonstrate as a systematic and quantitative effect on the reef environment of the GBR, which in some cases has fuelled debate in the literature (e.g. Macdonald et al. 2005; Carter 2006). Nevertheless, the GBR and its lagoon certainly receives many times the quantity of sediment and nutrients than it did before European settlement (e.g. Neil et al. 2002; Furnas 2003) and accordingly there is potential that ecosystems are exposed to elevated concentrations of herbicides and other chemicals (e.g. Haynes et al. 2000b). The global significance of the GBR and its associated ecosystems as the world's largest reef system adds considerable relevance to any method that might better determine the level of risk to which the GBR is exposed by terrestrial runoff.

An important physical parameter that influences the concentration of pollutants in a partially enclosed water body is the flushing time. The flushing time (or residence time) of a system is the approximate time that a parcel of water will remain within the system. A longer flushing time is an indication that solutes or suspended material reside for a longer time within the system. Generally, when the flushing time is combined with biological and chemical measurements, the quantitative effect on the water body caused by the particles and solutes can be determined. A long flushing time could, for example, allow increased concentration and accumulation of pollutants within the system. Flushing time can also be very important in the dispersal of larvae and larval recruitment.

For example, in Sydney Harbour, which has a very large volume, a narrow opening and therefore, restricted exchange, the flushing time is estimated to be as long as 225 days (Das et al. 2000). There is thus the potential for high concentrations of pollutants to develop. Conversely, the GBR (Fig. 1) is a very open system that is well connected to the Coral Sea through passages between the reef matrix, and therefore, is likely to have a shorter flushing time. Irrespective of whether nutrients, pesticides or other solutes are of concern, in simple oceanographic terms the flushing time of the lagoon is clearly an important parameter in determining concentrations.

The definition of 'flushing time' ranges in the literature (Monsen et al. 2002). Geyer et al. (2000: p. 1546) defined flushing time as 'the ratio of the mass of a scalar in a reservoir to the rate of renewal of the scalar'. However, this definition does not imply that there is complete removal of the mass of the scalar in this time. Instead, the concentration of the mass will often fall exponentially but will never be completely removed. For this reason it is often convenient to define the flushing time as the time for the concentration of a tracer to fall to within 1/e (0.37) of its original value (Prandle 1984; Choi and Lee 2004).

It is only recently that significant attention has been given to the flushing time of the GBR lagoon. Hancock et al. (2006) estimated flushing times and effective diffusion coefficients 


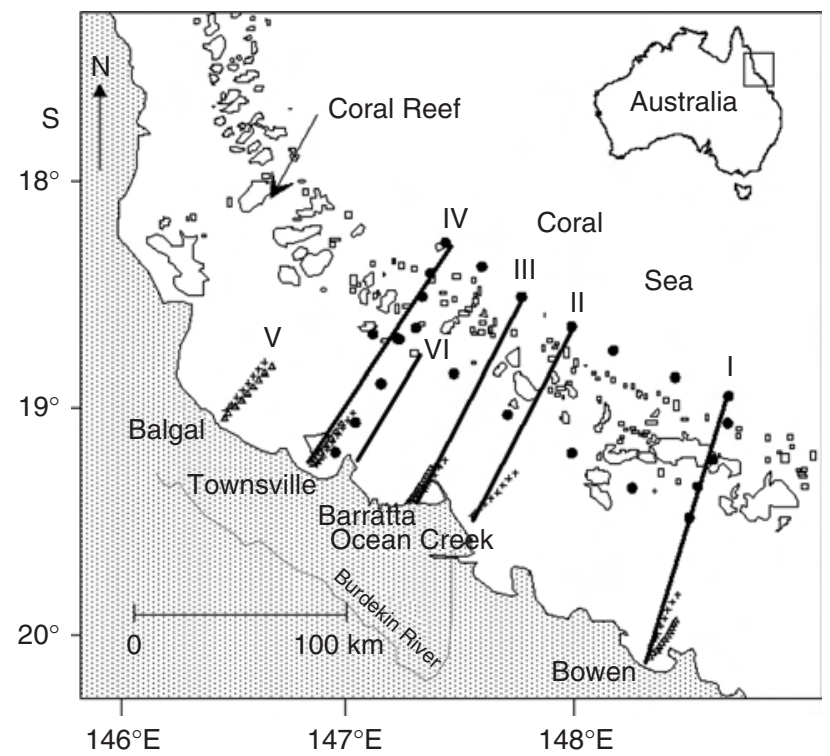

Fig. 1. Location of six conductivity-temperature-depth (CTD) transects in the Great Barrier Reef lagoon. The inshore $30 \mathrm{~km}$ of transects I, III, IV, V $(\Delta)$ were undertaken in July $11-17,2005$. The inshore $30 \mathrm{~km}$ of transects I-V $(\times)$ were undertaken in November 18-22, 2005. The inshore $50 \mathrm{~km}$ transect VI is the transect of Wolanski and Jones (1981) taken in 1979. The black dots show the positions of profiles taken in 28-30 November 2005.

using data of the abundance of radionuclides released from the sediment. This work used a very simple diffusion model to parameterise the mixing processes. Hancock et al. (2006) described relatively high diffusion coefficients and short flushing times by using the definition of the flushing time as the time for the concentration of a tracer to fall to within $1 / e(0.37)$ of its original value. The inner lagoon waters mixed with those of the outer lagoon with a flushing time of 18 days and 45 days for the two regions they considered, one in the northern GBR and the other in the central GBR. Diffusion coefficients ranged from 140 to $240 \mathrm{~m}^{2} \mathrm{~s}^{-1}$ in the inner lagoon to a maximum of $500 \mathrm{~m}^{2} \mathrm{~s}^{-1}$ for the outer lagoon.

A completely different approach to determine the flushing time of the GBR lagoon was employed by Luick et al. (2007). In contrast to the simple model of Hancock et al. (2006) and extensive use of radionuclide data, Luick et al. (2007) applied a multi-nested two-dimensional numerical model to determine the length of time that introduced particles would remain in the lagoon. It was found that particles introduced into Halifax Bay in the central GBR region in February at the peak of the wet season would be mainly advected northwards along shore, and retained within the confines of the lagoon for long periods until they exited near the Torres Strait. The implication is that very little cross-shelf mixing occurred. In contrast, for particles introduced in August at the peak of the dry season, the primary direction of movement was along shore to the south-east, but again with very little offshore mixing processes. Flushing times inferred from these model outputs indicated flushing times of the lagoon may be very long ( $\sim 6$ months) and the transport of particles is controlled by long-shelf advective processes not cross-shelf diffusion. Thus, it is evident that there is a significant conflict between the work of Hancock et al. (2006) and Luick et al. (2007), which requires attention.

In part to resolve this conflict, the current paper uses a different technique to determine the flushing time. The method herein is similar to that of Hancock et al. (2006) in that the calculations are based on concentration data and the use of a simple one-dimensional diffusion model. It is different to both of the previous approaches in its use of salinity as a conservative passive tracer. Salinity, or salt concentration, is a powerful tool that has often been used to determine flushing and mixing rates on continental shelves and estuaries (e.g. Nunes and Lennon 1986; Burling et al. 1999; Ridd and Stieglitz 2002). Salt is a conservative material and if salt and freshwater fluxes are known, it is often possible to develop models to describe exchange processes. Salinity has the further advantage that it is an easy parameter to measure, unlike radionuclides, and considerable archival data already exists.

Evaporation produces salinities at the coast of the GBR lagoon that can be roughly $1 \mathrm{ppt}$ higher than normal seawater values (Walker 1981, 1982). During the dry season, when freshwater river inflow is negligible, the magnitude of the salinity elevation is dependent on the evaporation rate, and the degree of mixing with water from the Coral Sea. By using extensive measurements of the along and across-shelf salinity, and evaporation rates, it is possible to calculate the flushing time and large-scale diffusion coefficients of water in GBR lagoon. Confining the analysis to the dry season simplifies the analysis considerably because during the wet season a detailed knowledge of highly variable river discharges would be required to accurately calculate the salinity budget. Although the calculations of flushing time make use of the salinity data taken from the dry season, it is most likely that the flushing times in the wet season are similar, because with the exception of baroclinic flows, the physical processes of water movement and exchange with the Coral Sea are similar in the dry and wet seasons.

This paper uses both archival and new dry season hypersalinity data to determine the flushing time of the lagoon. The archival data are based on a year-long record of fortnightly sampling along a cross-shelf transect of salinity measurements taken by Wolanski and Jones (1979). These data give an invaluable insight into temporal variations in the hypersaline coastal fringe but only give very limited information about the spatial variations in salinity. In order to redress this shortcoming, the new data collected specifically for this work are a sequence of several shore-normal transects over a $180-\mathrm{km}$ length of coastline. These data allow estimations of the long-shelf salinity gradient and long-shelf advective fluxes.

\section{Location}

The 2000-km long GBR borders the continental shelf of the tropical North Queensland coast of Australia and is considered the world's largest coral reef system (Fig. 1). The main reef matrix of the GBR is located well offshore, generally between 20 and $150 \mathrm{~km}$ from the coast. The sheltered GBR lagoon is separated from the waters of the Coral Sea by the main reef matrix and although the middle lagoon has relatively few reefs, it contains other important benthic ecosystems such as seagrass and $\mathrm{Hal}$ imeda beds (Schaffelke et al. 2005). Open ocean water can enter the lagoon through the passages in the outer reef (cross-shelf 
exchange) or from the large southern opening of Capricorn Passage. An additional opening is at the northernmost extent of the reef in the Torres Strait. The current study is primarily concerned with the dry tropics section of the central GBR lagoon area that is over $500 \mathrm{~km}$ north of the Capricorn Passage.

The central GBR continental shelf is relatively flat, with an average slope of $\sim 1: 2000$ and no major changes in slope except for at the continental shelf break which is the seaward extremity of the GBR. The slope is very constant for the outer and middle shelf $(\sim 1: 2000)$, but steepens to $\sim 1: 1000$ close to the coast where it intersects the shore-connected wedge of modern sediment.

Particles and solutes enter the lagoon via rivers, most of which only have significant discharge in short events during the wet season (January-April) (Furnas 2003). The 180-km-long section of the GBR of primary interest in the current study covers latitudes $20.2-18.3^{\circ} \mathrm{S}$, which form a significant fraction of the dry topics region of the North Queensland coast. The freshwater input in this area after the wet season is effectively zero (Wolanski and Jones 1981), an observation that considerably simplifies the application of the two models developed in this work because the salinity can be used as a conservative tracer.

\section{Salinity exchange process in the GBR lagoon}

The most common example of a diffusive process is random turbulence common to most flows. These diffusive fluxes can be greatly enhanced by non-random processes, such as velocity shear (Taylor 1954). In the GBR lagoon, the large eddies that form behind reefs (Wolanski et al. 1996) create mesoscale turbulence that can be parameterised with a diffusion coefficient. These wakes are in the order of a kilometre across and have typical velocity scales in the order of $0.1 \mathrm{~m} \mathrm{~s}^{-1}$. In addition to turbulent diffusion, there are a range of processes that may not be random in nature but which contribute to the cross-shelf dispersion of material within the GBR, some examples of which are portrayed in Fig. 2 and include: long-shelf variation in wind stress (Fig. 2a); removal of shelf waters from the lagoon by the East Australia Current (EAC) when it impinges onto the shelf (Fig. 2b); and shelf water dispersal by processes in the vertical plane (Fig. $2 c-e$ ). These processes are density-driven circulation by freshwater and hypersaline plumes, and circulation driven by wind-induced water-level variations. In each case flows are stratified, with water moving onshore at one level and offshore at another level.

None of the processes summarised in Fig. 2 give rise to a net flux of water into the GBR lagoon but each can be responsible for exchanging solutes if a concentration gradient exists. Provided one considers a depth and long-shore average of concentration, the fluxes are diffusive in nature, i.e. the fluxes are directly proportional to a concentration gradient. At any given location in the GBR lagoon, all of the processes shown in Fig. 2 may be occurring but there are insufficient data to quantify each separately. Instead, it is convenient to combine all the diffusion coefficients associated with these types of processes to form an assumed total diffusion coefficient that controls the depth and long-shelf average of the solute concentration.

Long-shore processes may also be responsible for the exchange of water between the GBR lagoon and the Coral Sea, particularly at the southern opening to the lagoon. The longshore current velocity is affected primarily by wind stress and the influence of the EAC (Brinkman et al. 2002). The dominant wind direction in this region is from the south-east during the trade wind season that starts around April and continues with diminishing intensity until around October. The trade winds tend to produce a northward-directed current close to the shore and oppose the influence of the EAC further offshore. The EAC has a typical southward-directed surface speed of around $0.3 \mathrm{~m} \mathrm{~s}^{-1}$ in the Coral Sea and produces a net mean southerly flow of small magnitude over much of the outer reef matrix.

Table 1 summarises literature values of long-term averaged values of long-shore current. Data from the dry season have been reported where possible to calculate mean currents. The long-shore current measured in Abbot Bay showed a very small long-shore current of less than a few $\mathrm{cm} \mathrm{s}^{-1}$ and below the resolution of the current meter to even resolve the direction without ambiguity (P. Ridd and T. Stieglitz, James Cook University, unpubl. data). Just to the north of Abbot Bay off Cape Upstart, Wolanski and Pickard (1985) measured currents in the dry season between $5 \mathrm{~cm} \mathrm{~s}^{-1}$ and $-10 \mathrm{~cm} \mathrm{~s}^{-1}$. Cape Upstart is a major coastal protuberance that impinges into the lagoon and it is likely that long-shore currents will be magnified locally around this obstacle.

As part of a shore-normal transect of current meters from Cape Cleveland to the Queensland trough, Burrage et al. (1991) measured a very small long-shore current of around $1.5 \mathrm{~cm} \mathrm{~s}^{-1}$ at a distance of around $20 \mathrm{~km}$ offshore of Cape Cleveland in 1985. Further offshore, at a distance of $45 \mathrm{~km}$ from the coast, Burrage et al. (1991) measured a net southward long-shore current of around $7 \mathrm{~cm} \mathrm{~s}^{-1}$. On the outer shelf in a region affected by the EAC, Burrage et al. (1991) measured a southward current of around $5 \mathrm{~cm} \mathrm{~s}^{-1}$.

In the northern sector of the GBR and outside the area of direct interest in this paper, Wolanski and Pickard (1985) measured long-shore currents near Green Island to range from 5 to $-15 \mathrm{~cm} \mathrm{~s}^{-1}$, both northward and southward flows. Green Island is also in an area affected by a major protuberance of the coast (Cape Grafton) and field observations suggest significant amplification of current in the general region of this site (M. Heron, James Cook University, unpubl. data).

Although it would be desirable to have more data on longshore currents close in-shore, the published data indicate that under typical dry season conditions currents are in the order of $5 \mathrm{~cm} \mathrm{~s}^{-1}$ or less except in areas adjacent to major coastal protuberances. This information can be used to estimate longshore advective fluxes.

\section{Materials and methods}

\section{Evaporation rates for the GBR}

Estimates of evaporation rates based on direct meteorological data in the GBR lagoon have not been recorded routinely, and thus estimates of the yearly average of evaporation for the GBR lagoon were sourced from world maps of air-sea fluxes as summarised in Table 2 . These estimates use a variety of methods to determine evaporation rates. The Southampton Oceanography Centre (SOC) and University of Wisconsin Milwaukee/Comprehensive Ocean-Atmosphere Data Set 
(a)

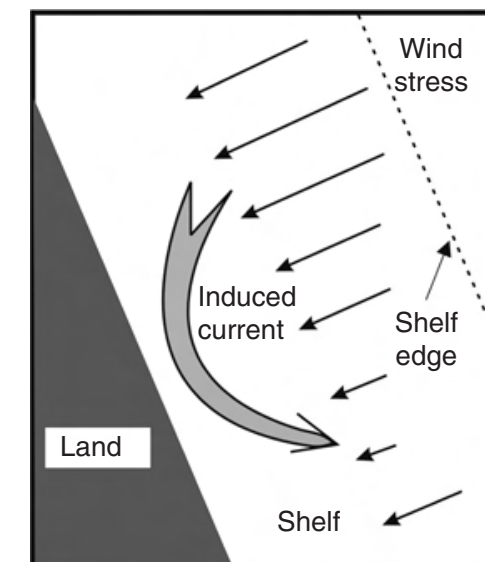

(b)

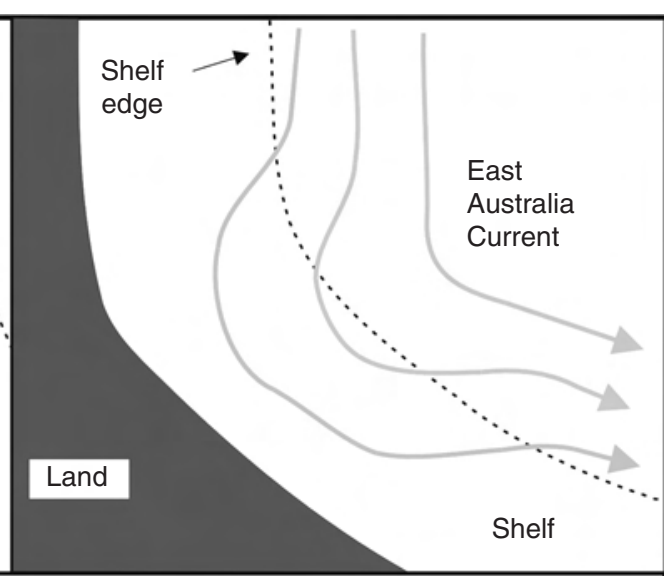

(c)

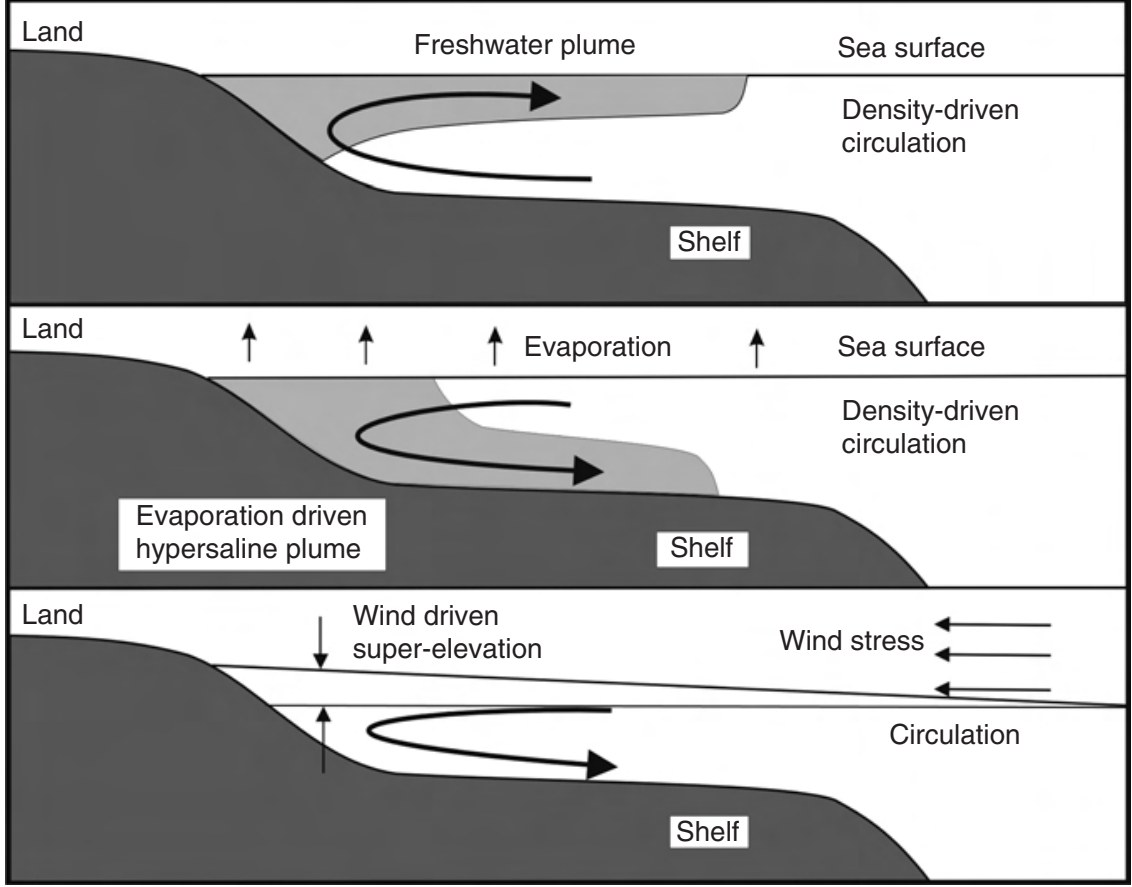

Fig. 2. Mechanisms that can cause dispersion of solutes from the Great Barrier Reef lagoon: $(a)$ wind shear; $(b)$ meanders of the East Australia Current onto the continental shelf; $(c)$ river plumes; $(d)$ hypersaline plumes; and $(e)$ wind driven onshore surface flow and offshore bottom flow.
(UWM/COADS) estimates are based on in situ data from ships and buoys. The European Centre for Medium Range Weather Forecasting (ECMWF) reanalysis and the National Centre for Environmental Prediction/The National Centre for Atmospheric Research (NCEP/NCAR) estimates combine the output of model forecast and observation. Much of these data are presented and explained on http://www-meom.hmg.inpg.fr/Web/Atlas/Flux/ (verified August 2007), but the primary references are given in Table 2.

It can be seen from Table 2 that estimates of evaporation range from 110 to $170 \mathrm{~mm} \mathrm{month}^{-1}$ ( $\left.\sim-6 \mathrm{~mm} \mathrm{day}^{-1}\right)$. Although there may be some detailed variation in the evaporation rates over the lagoon, evaporation is primarily controlled by wind speed, water and air temperature and humidity. These are unlikely to vary greatly over the lagoon except during conditions of westerly winds where dry continental air may cause a significantly different evaporation rate inshore. For the work that follows, it will be assumed that the evaporation rate is $5 \mathrm{~mm}^{\text {day }}{ }^{-1} \pm 25 \%$. In the future it would be interesting to use actual local in situ meteorological data for the evaporation data rather than the compilations used in this work.

\section{Salinity data for the GBR}

Although considerable published data are available for the GBR, almost all of them are collected during the wet season and with a focus on river plumes.

\section{Archival salinity data}

The most complete dataset of cross-shelf salinity in the GBR lagoon were collected by Wolanski and Jones $(1979,1981)$. 
Table 1. Measurements of long-term averages of longshore currents at various locations in the Great Barrier Reef lagoon Mean current is positive if directed northward, $x$ and $L$ is defined in Fig. 3. $x / L=1$ is the coast and $x / L=0$ is the shelf break

\begin{tabular}{|c|c|c|c|c|c|c|}
\hline Location & Position & $\begin{array}{l}\text { Mean current } \\
\left(\mathrm{cm} \mathrm{s}^{-1}\right)\end{array}$ & $\begin{array}{l}\text { Distance from } \\
\text { coast }(\mathrm{km})\end{array}$ & $\begin{array}{l}\text { Relative position } \\
\text { onshelf }(x / L)\end{array}$ & $\begin{array}{l}\text { Time period } \\
\text { of observation }\end{array}$ & Reference \\
\hline Abbot Bay & $19^{\circ} 50.947^{\prime} \mathrm{S}, 147^{\circ} 52.035^{\prime} \mathrm{E}$ & $1-2$ & 1 & 1 & $1 / 8 / 02-5 / 9 / 02$ & Ridd and Stieglitz, unpubl. data \\
\hline Cape Upstart & $\sim 19^{\circ} 40^{\prime} \mathrm{S}, 147^{\circ} 50^{\prime} \mathrm{E}$ & 5 & $\sim 15$ & 0.85 & $10 / 80-12 / 80$ & Wolanski and Pickard (1985) \\
\hline Cape Upstart & $\sim 19^{\circ} 40^{\prime} \mathrm{S}, 147^{\circ} 50^{\prime} \mathrm{E}$ & -10 & $\sim 15$ & 0.85 & $5 / 82-10 / 82$ & Wolanski and Pickard (1985) \\
\hline $\begin{array}{l}\text { North of Cape } \\
\text { Cleveland }\end{array}$ & $19^{\circ} 4.5^{\prime} \mathrm{S}, 147^{\circ} 4.2^{\prime} \mathrm{E}$ & 1.5 & 20 & 0.8 & $14 / 5 / 85-8 / 8 / 85$ & Burrage et al. (1991) \\
\hline $\begin{array}{l}\text { North of Cape } \\
\text { Cleveland }\end{array}$ & $18^{\circ} 48.8^{\prime} \mathrm{S}, 147^{\circ} 8.5^{\prime} \mathrm{E}$ & -6.6 & 45 & 0.55 & $1 / 9 / 85-26 / 11 / 85$ & Burrage et al. (1991) \\
\hline Outer Shelf & $18^{\circ} 29.1^{\prime} \mathrm{S}, 147^{\circ} 20.4^{\prime} \mathrm{E}$ & -5 & 80 & 0.2 & $6 / 5 / 85-26 / 11 / 85$ & Burrage et al. (1991) \\
\hline Green Island & $\sim 16^{\circ} 40^{\prime} \mathrm{S}, 146^{\circ} 00^{\prime} \mathrm{E}$ & -15 & 20 & 0.65 & $8 / 81-12 / 81$ & Wolanski and Pickard (1985) \\
\hline Green Island & $\sim 16^{\circ} 40^{\prime} \mathrm{S}, 146^{\circ} 00^{\prime} \mathrm{E}$ & 5 & 20 & 0.65 & $8 / 82-10 / 82$ & Wolanski and Pickard (1985) \\
\hline
\end{tabular}

Table 2. Estimates of the evaporation rates over the Coral Sea and GBR lagoon averaged over 1 year

SOC, Southampton Oceanography Centre; UWM/COADS, University of Wisconsin Milwaukee/Comprehensive Ocean-Atmosphere Data Set; ECMWF, European Center for Medium range Weather Forecasting; NCEP/ NCAR, The National Centers for Environmental Prediction/The National Center for Atmospheric Research

\begin{tabular}{lcl}
\hline Information source & $\begin{array}{c}\text { Evaporation rate } \\
\left(\mathrm{mm} \text { month }^{-1}\right)\end{array}$ & Reference \\
\hline SOC & $110-130$ & Josey et al. $(1998)$ \\
UWM/COADS & $140-160$ & da Silva et al. $(1994)$ \\
ECMWF reanalysis & $160-170$ & Gibson et al. $(1997)$ \\
NCEP/NCAR & $140-160$ & Kalnay et al. $(1996)$ \\
\hline
\end{tabular}

These data represent a series of salinity measurements taken throughout 1979 at six sites on the shore-normal transect VI shown in Fig. 1 and comprise a total of 34 fortnightly transects over the course of the year. Water samples for salinity analysis were collected at six equally spaced depths through the water column at all locations. In order to remove short-timescale variations from the data, a running average of five successive transects $(\sim 2$ months of data) was used in the analysis.

\section{New salinity data}

Water temperature, salinity and depth measurements were obtained using a Sea Bird SBE 19 Seacat Profiler (Sea-bird Electronics, Inc., Bellevue, WA) at the locations shown on Fig. 1 and Table 3 (transects I-V) in 2005. During each vertical profile, the conductivity-temperature-depth (CTD) recorder sampled every $0.5 \mathrm{~s}$ and the descent rate was set at $\sim 1 \mathrm{~m} \mathrm{~s}^{-1}$. The distance between the vertical profiling stations along each transect was set at $1-2 \mathrm{~km}$. Positions were determined using a GPS system (referenced to World Geodetic System 1984 revision(WGS 84)), with a precision better than $50 \mathrm{~m}$. Between 11 and 17 July 2005, a series of four shore-normal salinity transects (I, III, IV and V) extending $\sim 30 \mathrm{~km}$ from the coast were taken. A second set of cross-shelf salinity transects (I, II, III and IV) extending about the same distance were taken at the end of the dry season between

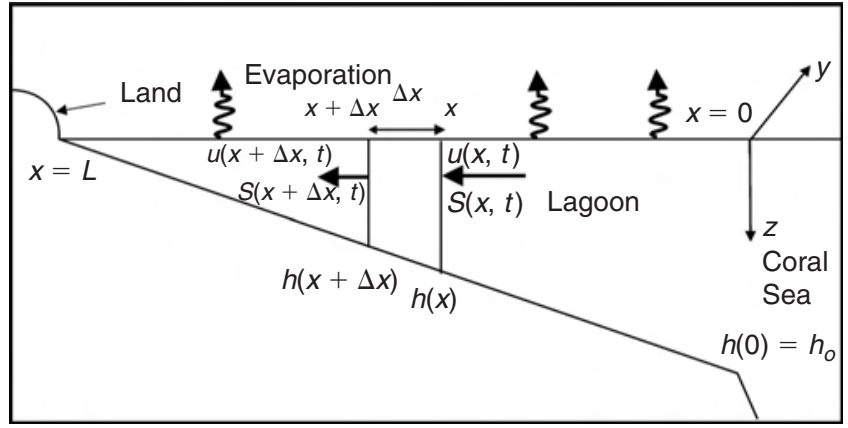

Fig. 3. Cross section across the Great Barrier Reef lagoon defining variables and geometry. The water depth is assumed to vary linearly from zero at the coast to $h_{o}$ at the shelf break, the $u$ is the onshore evaporation driven current, $L$ is the width of the shelf.

18 and 22 November. In addition to these short cross-shelf transects, a series of measurements were taken between 28 and 30 November 2005, primarily in two along-shelf transects in the Coral Sea and middle GBR lagoon (Fig. 1).

\section{Exchange model}

Here we present an exchange model to determine the flushing time in the GBR lagoon using the salinity as a tracer. In the dry season, freshwater input to the central GBR lagoon from rivers is negligible and hypersaline conditions exist close to the coast. By the end of the dry season, the water salinity can be considered to be in a steady state (Walker 1981).

Consider the volume element of length $\Delta x$, unit long-shore length and salinity $S(x)$ shown in Fig. 3. Water mass is exchanged between the Coral Sea and this volume by various processes at a rate $q$. In addition, water must be added to the element at a rate $E \Delta x$, where $E$ is the evaporation rate. The rate at which salt is brought into the element is $(E \Delta x+q) S_{c s}$, where $S_{c s}$ is the salinity of the water from the Coral Sea. Salt is lost from the element at a rate $q S(x)$. For equilibrium conditions, the salt added equals the salt lost and

$$
q=E \Delta x S_{c s} /\left(S(x)-S_{c S}\right)
$$


Table 3. The summary of conductivity-temperature-depth (CTD) transects I to V measured in 2005

\begin{tabular}{lllc}
\hline Location & Date: start-finish time & Start, finish lat. (S) & Start-finish long. (E) \\
\hline Bowen (I) & $11 / 7: 09: 09-11: 32$ & $-20.0640,-19.899$ & $148.2684-148.3782$ \\
& $18 / 11: 10: 19-12: 32$ & $-20.0469,-20.0395$ & $148.1464-148.2663$ \\
& $29 / 11-11 / 30$ & $-19.4232,-18.8904$ & $148.4372-148.6091$ \\
Ocean Creek (II) & $19 / 11: 08: 44-10: 45$ & $-19.4962,-19.3167$ & $147.5188-147.7002$ \\
& $29 / 11-30 / 11$ & $-19.1396,-18.8081$ & $147.9236-148.3754$ \\
Barratta (III) & $12 / 07: 10: 54-12: 23$ & $-19.4158,-19.2614$ & $147.2689-147.3884$ \\
& $19 / 11: 12: 00-13: 20$ & $-19.2504,-19.4005$ & $147.4130-147.3125$ \\
Townsville (IV) & $29 / 11-10 / 11$ & $-18.9707,-18.5880$ & $147.6423-147.9222$ \\
& $14 / 07: 07: 56-09: 29$ & $-19.2759,-19.0618$ & $146.8631-147.0103$ \\
Balgal (V) & $20 / 11: 06: 06-07: 46$ & $-19.2838,-19.0639$ & $146.8721-147.0223$ \\
& $29 / 11-30 / 11$ & $-19.1362,-18.2193$ & 21.2 \\
& $14 / 07: 10: 54-12: 40$ & $-18.8705,-19.0894$ & 21.7 \\
& $20 / 11: 09: 10-10.43$ & $-18.8407,-19.0639$ & $146.8897-147.3707$ \\
& & 29.4 & $146.6866-146.4892$ \\
\end{tabular}

Defining the flushing time to be $t=h \Delta x / q$, the flushing time is given by the expression

$$
t=h\left(S(x)-S_{c s}\right) / E S_{c S}
$$

Equation 2 is a simple closed-form expression that can be used to evaluate the flushing time of the water at any given location across the shelf. In addition to the evaporation rate, all that is required to calculate flushing time is the water depth, shelf salinity and Coral Sea salinity. It should be noted that the salt concentration in units of $\mathrm{kg} \mathrm{m}^{-3}$ is numerically the same as the salinity (as measured in ppt) and these two terms are used interchangeably in the following text.

\section{Diffusion model}

A depth-averaged and long-shore-averaged advection-diffusion equation is formulated for the GBR lagoon. In common with the exchange model above, it is assumed that there is no freshwater input. The assumption of no freshwater input is easily satisfied for most of the GBR coast for the second half of the year. If the water depth is assumed to vary linearly from zero at the coast to $h_{o}$ at the shelf break (Fig. 3), the magnitude of the onshore evaporation driven current, $u$, is found to be

$$
u=\frac{E L}{h_{o}}
$$

where $L$ is the width of the shelf. For this geometry, $u$ does not vary across the shelf and is in the order of $0.1 \mathrm{~mm} \mathrm{~s}^{-1}$, consistent with the gentle and consistent slope of the continental shelf.

A diffusive process is defined as a process where the transport is proportional to a concentration gradient, according to Fick's law,

$$
J_{d}(x)=-k(x) \frac{\partial S(x)}{\partial x}
$$

where $J_{d}(x)$ is the diffusive flux in the $x$ direction, $S(x)$ is the salinity, and $k(x)$ is a diffusion coefficient.

The offshore-directed diffusion salt flux (Eqn 4) is opposed by an onshore-directed salt flux resulting from the evaporation driven current given in Eqn 3. The diffusion coefficient in this work is assumed to take an exponential form. In addition, because of the possibility of higher diffusion coefficients occurring in the offshore region owing to large-scale turbulence generated by flow around reefs, the shelf was divided into an inshore and offshore region with different diffusion parameters in each region i.e.

$$
\begin{aligned}
& k(x)=k_{s 1} \mathrm{e}^{-\beta_{1} x} \quad\left(x<x^{\prime}\right) \\
& k(x)=k_{s 2} \mathrm{e}^{-\beta_{2}\left(x-x^{\prime}\right)} \quad\left(x>x^{\prime}\right)
\end{aligned}
$$

where $x$ is the cross-shelf position with $x=0$ being defined at the shelf break as in Fig. 3. Coefficients $\beta_{1}$ and $\beta_{2}$ reflect the decay of the diffusion coefficient across the shelf for the offshore and inshore regions respectively. $k_{s 1}$ and $k_{s 2}$ represent the diffusion coefficient at $x=0$ (shelf break) and at $x=x^{\prime}$ respectively. $x^{\prime}$ is the boundary between the inshore and offshore regions of the shelf. The value of $k(x)$ was required to be similar on either side of the boundary between the inshore and offshore regions i.e. at $x=x^{\prime}$.

Assuming the water is vertically well mixed in the dry season, by applying conservation laws, it can be shown that the salt concentration of the lagoon $(S(x, t))$ is given by.

$$
\begin{aligned}
\frac{\partial S(x, t)}{\partial t}= & \frac{E L S(x, t)}{h_{o}(L-x)}-\frac{E L}{h_{o}} \frac{\partial S(x, t)}{\partial x}-\frac{k(x)}{(L-x)} \frac{\partial S(x, t)}{\partial x} \\
& -\beta(x) k(x) \frac{\partial S(x, t)}{\partial x}+k(x) \frac{\partial^{2} S(x, t)}{\partial x^{2}}
\end{aligned}
$$

It should be noted that Eqn 6 is a form of the 1D, depth-averaged advection-diffusion equation.

$$
h(x) \frac{\partial S}{\partial t}+\frac{\partial}{\partial x}(u h S)=\frac{\partial}{\partial x}\left[k h \frac{\partial S}{\partial x}\right]
$$

given in Fischer et al. (1979).

In Eqn 6, the first two terms on the right-hand side represent the contribution to the rise in salinity owing to the evaporation on the surface. The last three terms represent the influence of diffusive (mixing) processes. $\beta(x)$ takes the value of $\beta_{1}$ or $\beta_{2}$ depending on the value of $x$ (see Eqn 5). 
Equation 6 describes the evolution with time of the crossshelf salt concentration as a function of the geometry of the shelf, evaporation rate and cross-shelf diffusion coefficient. This equation can be solved subject to suitable boundary conditions for $S(x, t)$, i.e. the assumed constant salinity of the Coral Sea. With measurements of $S(x, t)$ and $E$ it is possible to determine the cross-shelf diffusion coefficient $k(x)$ by adjusting $k(x)$ so that the measured spatial and temporal changes in salinity are matched by the model calculations of $S(x, t)$. With this key parameter determined, it is then possible to calculate the evolution of the concentration distribution of any conservative tracer.

The flushing time for water in various locations of the lagoon were determined by considering the concentration of a conservative tracer (not necessarily salinity) by the following steps. (1) A boundary condition of zero concentration was imposed at the shelf break $(x=0)$. (2) An initial condition was imposed consisting of a constant concentration within a particular section of the shelf and zero elsewhere. For example, to calculate the flushing time for a $10-\mathrm{km}$ wide strip from the coast, then the initial condition would be a constant concentration within $10 \mathrm{~km}$ from the coast and zero elsewhere. (3) Eqn 6 was used to determine the evolution of the concentration distribution and to determine the time for a mass of solute within the whole lagoon $(M)$ to drop to $1 / e(0.37)$ of its original value $\left(M_{0}\right)$, i.e. when.

$$
M=\frac{1}{e} M_{0}
$$

or

$$
\int_{x=0}^{x=L} S(x, t) h(x) d x=\frac{1}{e} \int_{x=0}^{x=L} S(x, 0) h(x) d x
$$

A numerical scheme is the most practical method of solving Eqn 6 . The cross-shelf dimension is broken into $N$ grids cells and an initial concentration in each of the cells is stipulated. The change in concentration at each of the cells is determined after a time step of $\Delta t$. This is done by evaluating each of the five terms on the right-hand side of Eqn 3 and multiplying the sum by $\Delta t$. Terms involving the first spatial derivative of $S(x, t)$ are evaluated using.

$$
\frac{\partial S}{\partial x}=\frac{S_{n+1}-S_{n-1}}{2 \Delta x}
$$

and the term involving the second derivative is evaluated using.

$$
\frac{\partial^{2} S}{\partial x^{2}}=\frac{S_{n+1}-2 S_{n}+S_{n-1}}{\Delta x^{2}}
$$

where $S_{n}$ represents the concentration $S(x, t)$ in the $n$th grid-cell, and $n$ ranges from 1 to $N$. Care must be taken when evaluating the derivatives at the boundaries as the concentrations outside the model domain are required, i.e. where $n=0$ and $n=N+1$. At the offshore boundary, the most convenient solution is to set $S_{0}=S_{1}$, implying a constant concentration outside the shelf. At the land boundary $S_{N+1}$ was set equal to $S_{N}$.

Once the concentration at each of the cells is determined after the time step $\Delta t$, the process is repeated using the new concentration values in the calculation. For a shelf width of $100 \mathrm{~km}$ and $n=300$, it was found that the model was stable if a time step of $20 \mathrm{~s}$ was used. The model was checked to ensure convergence for the time-step and grid scale used. Further, the model was checked to ensure mass was conserved.
Another estimate of the diffusion coefficients can be made using the steady-state version of Eqn 7 integrated once with respect to $x$, using the condition that the net salt flux must be zero at steady state. This gives an explicit expression for $k(x)$ i.e.:

$$
k(x)=\frac{E L}{h_{o}} \frac{S}{\partial S / \partial x}
$$

\section{Results}

\section{Measured salinity variations in the GBR lagoon}

Fig. 4 shows the depth-averaged salinity variation on transect VI across the continental shelf over the course of the year 1979 together with discharge from the Burdekin River and rainfall. It can be seen that the salinity of the offshore sites varies by less than $1 \mathrm{ppt}$ over the course of the year. On the other hand, the salinity of the inshore sites varies by around 6 ppt over the year with low salinities during the wet season giving way to hypersaline values in the last three months of the year. It is interesting to note that at around Julian day 250 (early September) all locations have approximately the same salinity. After this time, the salinity of the inshore sites rises for $\sim 2$ months before reaching constant and presumed equilibrium salinity slightly in excess of $36 \mathrm{ppt}$. The freshwater input for the period after Day 250 is effectively zero and thus, this period is an ideal dataset to use in the model described above.

Fig. 5 shows the cross-shelf salinity profile (not including the salinity of the Coral Sea) for various times of the year during 1979, which was measured by Wolanski and Jones (1979).
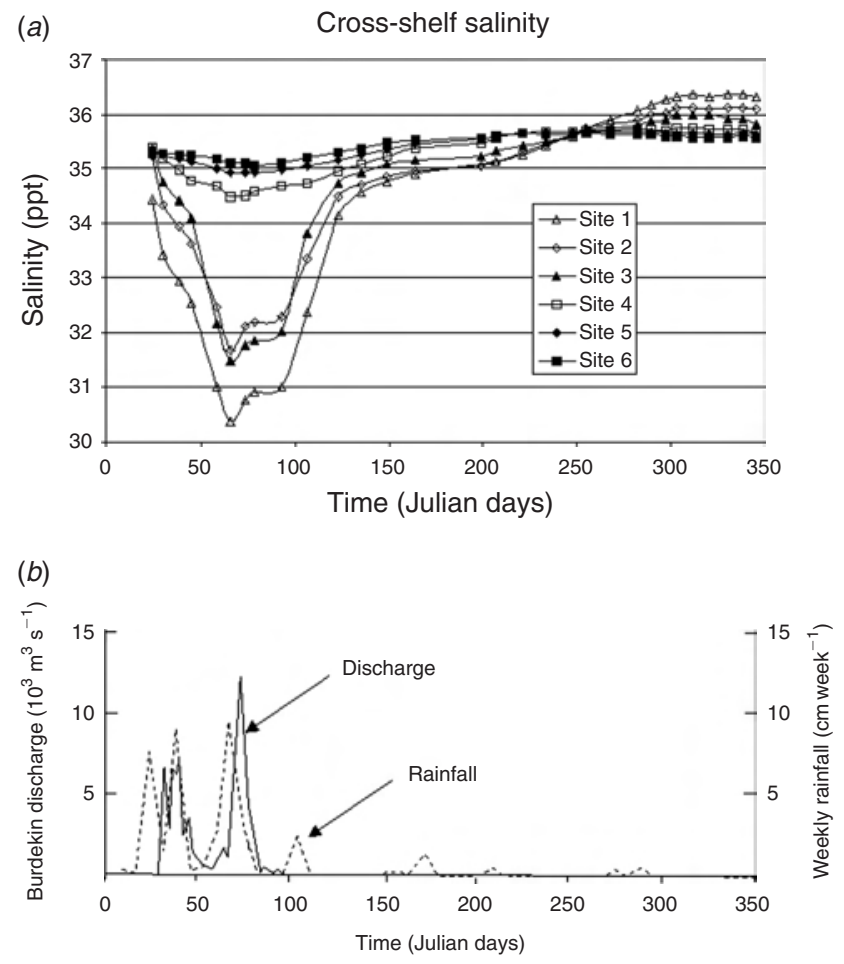

Fig. 4. (a) Salinity versus time at different locations across the shelf in 1979 (after Wolanski and Jones 1979). (b) Rainfall at Townsville and Burdekin river discharge in 1979 (after Wolanski and Jones 1981). 


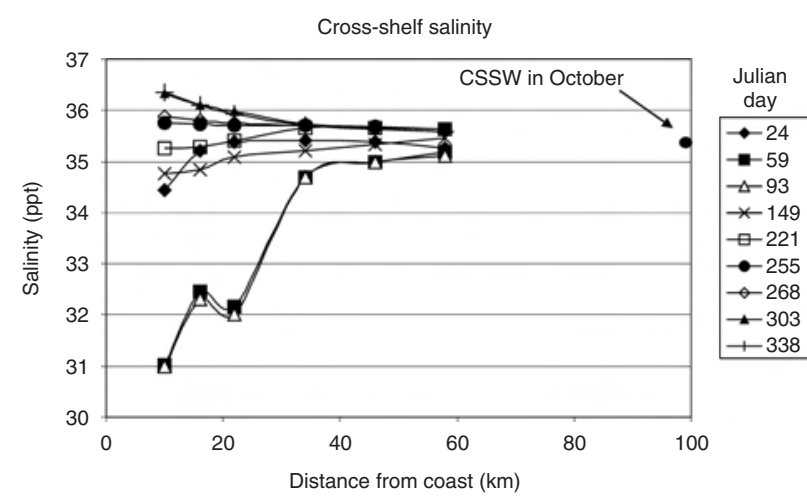

Fig. 5. Cross-shelf salinity for various times throughout 1979 measured along transect VI in Fig. 1 (after Wolanski and Jones 1979). Coral Sea Surface Water (CSSW) salinity is also shown.
It is notable that the largest gradients occur close to the shore, implying higher evaporation and lower dispersion close to the shore. Andrews (1983) measured the salinity of Coral Sea Surface Water (CSSW) to be 35.4-35.5 ppt during the latter part of the dry season. This is slightly lower than the most offshore value measured by Wolanski and Jones (1979) (salinity 35.6 ppt at $60 \mathrm{~km}$ from the shore) and is thus consistent with the hypothesis that slight hypersalinity occurs across the whole shelf.

The salinity distribution along the various transects in the lagoon in July 2005 is shown in Fig. $6 a-b$. The water was generally well mixed with typical salinity differences between the surface and the bed rarely exceeding $0.2 \mathrm{ppt}$. All transects showed significant hypersalinity close to the coast with elevations of up to $0.5 \mathrm{ppt}$ at the coast relative to water $15 \mathrm{~km}$ from the coast.

The salinity transects taken in November are shown in Fig. $6 c-d$. These transects are longer than transects measured (a) V (Balgal)_July

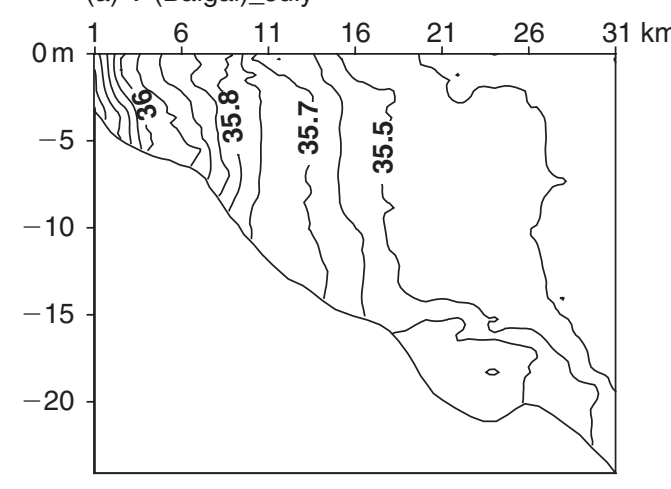

(c) IV (Townsville)_November (b) III (Barratta)_July

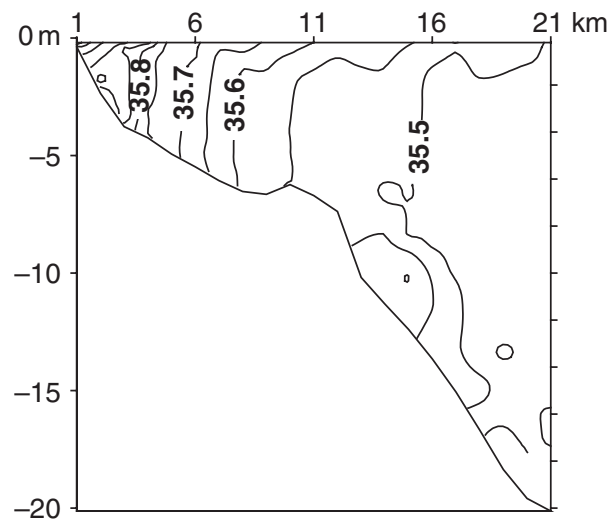

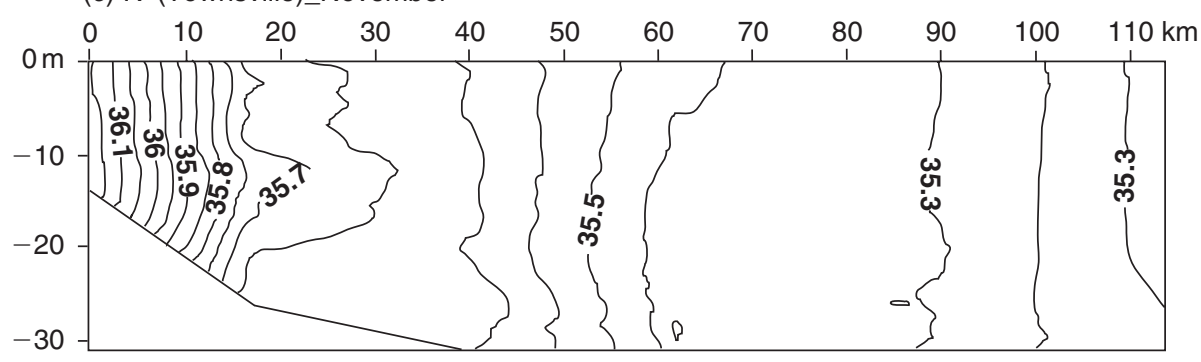

(d) I (Bowen)_November

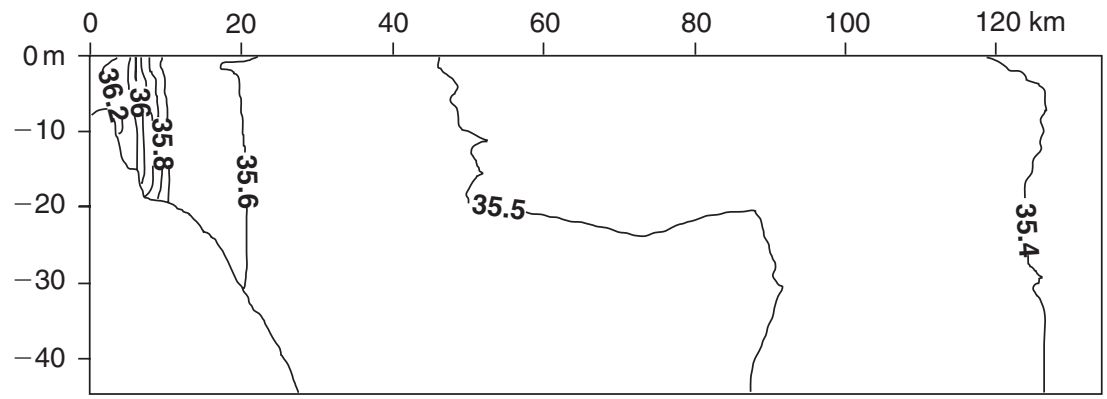

Fig. 6. Salinity profile contours (in ppt) in the Great Barrier Reef lagoon in July and November 2005. 
(a)

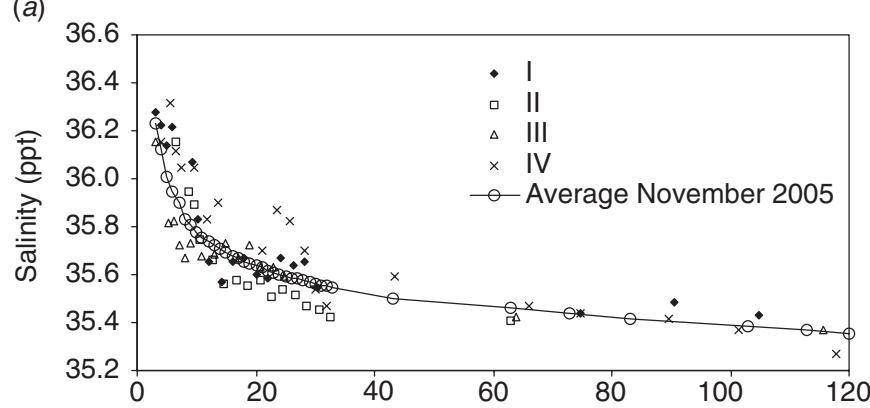

(b)

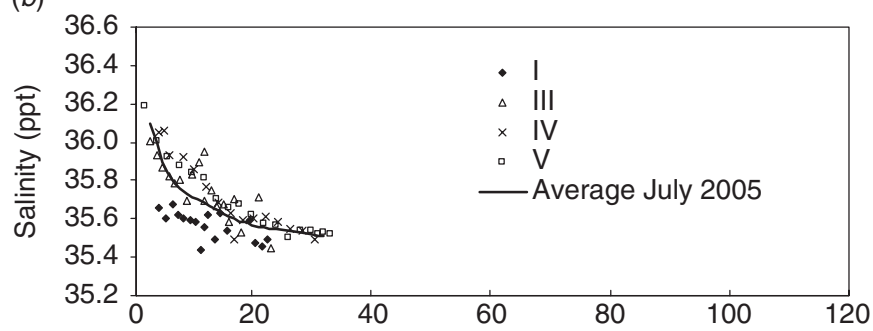

(c)

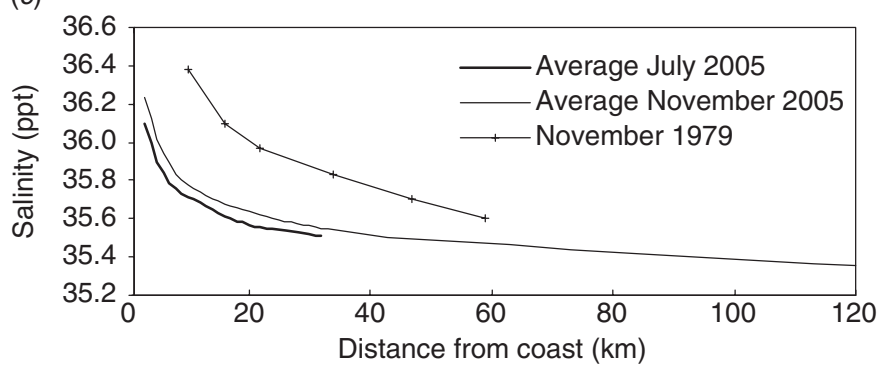

Fig. 7. Depth average salinity (ppt) in (a) Nov. 2005 along transects IIV and $(b)$ in July 2005 along transects I, III, IV, V. Fig. $4 c$ shows that the depth average salinity in July and November 2005 and November 1979 from Wolanski and Jones (1979).

in July and extend to the Coral Sea. The general inshore average salinity spatial variations in November were similar to those measured in July with typical salinity at the coast $\sim 0.5 \mathrm{ppt}$ higher than the water $15 \mathrm{~km}$ from the coast and $\sim 0.9 \mathrm{ppt}$ higher than the salinity in the Coral Sea. The water was mixed better compared with the water in July, with typical salinity differences between the surface and the bed rarely exceeding $0.05 \mathrm{ppt}$.

The depth-averaged salinity across the shelf is shown in Fig. $7 a-c$. Compared with the salinity values on the transect VI in November 1979 (Wolanski and Jones 1979), the salinity values in 2005 are low especially close to the coast, but all transects from July and November 2005 and November 1979 showed the hypersaline coastal water indicating that for this part of the coast, hypersaline conditions are the norm. One possible explanation for the higher values of salinity for transect VI is that this transect was offshore from Cape Cleveland, a major protuberance on the coast, and thus even a minor long-shore current will cause hypersaline inshore waters to be moved further offshore, thus increasing the salinity.

The long-shore salinity varies by $\sim 0.2$ over the $180 \mathrm{~km}$ of coastline, giving an along-shore salinity gradient of $10^{-6} \mathrm{ppt} \mathrm{m}^{-1}$. The across shelf salinity change is around $0.48 \mathrm{ppt}$

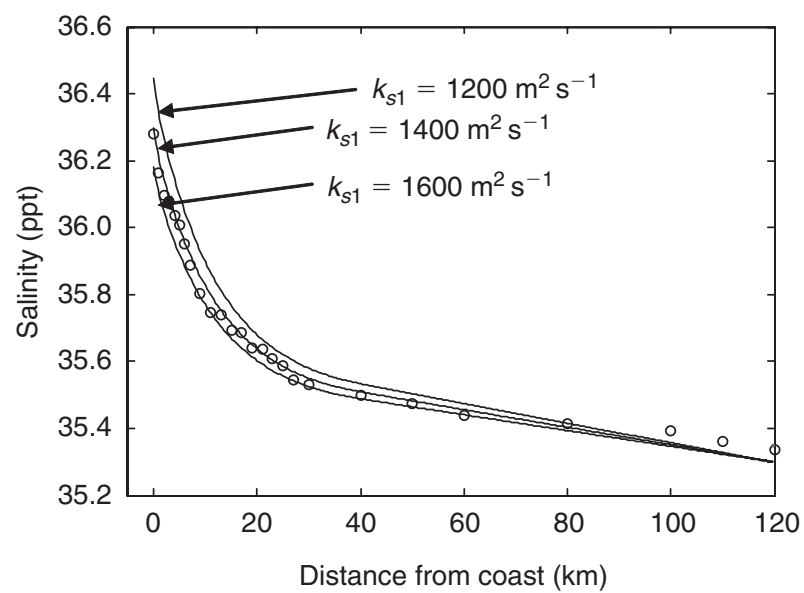

Fig. 8. Predicted Cross shelf salinity (ppt) distribution 50 days after an initial constant cross shelf salinity of 35.32 ppt based on Eqn 6. Evaporation rate was set at $5 \mathrm{~mm}$ day $^{-1}$, and the Coral Sea salinity was set at $35.32 \mathrm{ppt}$. Data points (open circles) represent measured depth average salinity measured in November 2005 (Fig. 7).

over the inshore $15 \mathrm{~km}$ and around $0.73 \mathrm{ppt}$ for the 120 $\mathrm{km}$ length (Fig. 7). The cross-shelf gradients thus vary from $3 \times 10^{-5} \mathrm{ppt} \mathrm{m}^{-1}$ to $6 \times 10^{-6} \mathrm{ppt} \mathrm{m}^{-1}$, which are 6-30 times the along-shore salinity gradient.

\section{Determining the diffusion coefficients}

The diffusion coefficients were determined by choosing the values of $k_{s 1}, k_{s 2}, \beta_{1}$ and $\beta_{2}$ that produced a cross-shelf salinity distribution, using Eqn 6, which was closest to the measured distribution as shown in Fig. 8. In this calculation, the initial condition was an assumed and constant cross-shelf salinity equal to the Coral Sea salinity of 35.32 ppt. The model was run for 50 days to produce a salinity distribution that was close to its equilibrium value. It should be noted that the field data (Wolanski and Jones 1979) indicate that equilibrium is reached in 50-70 days.

In order to put an upper and lower bound on the model input parameters, several model runs were performed using the range of input parameters. It was found that the value of $k_{s}$ played a dominant role in forcing the model output through the field data points. Fig. 8 shows the model output with $k_{s 1}$ set from 1200 to $1600 \mathrm{~m}^{2} \mathrm{~s}^{-1}$ that, respectively, produces salinities that are too high and too low compared with the field data. The time of 50 days corresponds to the near-steady-state condition. The best match between model output and field data is shown in Fig. 8 when $k_{s 1}=1400 \mathrm{~m}^{2} \mathrm{~s}^{-1}, \beta_{1} 0.01 \times 10^{-5} \mathrm{~m}^{-1}$, $k_{\mathrm{s} 2}=1390 \mathrm{~m}^{2} \mathrm{~s}^{-1}, \beta_{2}=7.4 \times 10^{-5} \mathrm{~m}^{-1}$ and $x^{\prime}=40 \mathrm{~km}(\operatorname{root}$ mean squared error $(\mathrm{RMSE})=0.03 \mathrm{ppt}$ ). The reason that the value of $\beta_{1}$ was required to be very small is to produce a small salinity variation offshore. $\beta_{2}$ was required to be large to produce the rapid rise in salinity close to the coast. The value of $x^{\prime}-40 \mathrm{~km}$-coincidentally corresponds to the break between the offshore main reef matrix and the inshore waters that are relatively devoid of reefs. Higher mixing owing to wakes behind reefs is likely a cause of the higher apparent diffusion coefficients in the offshore region. 


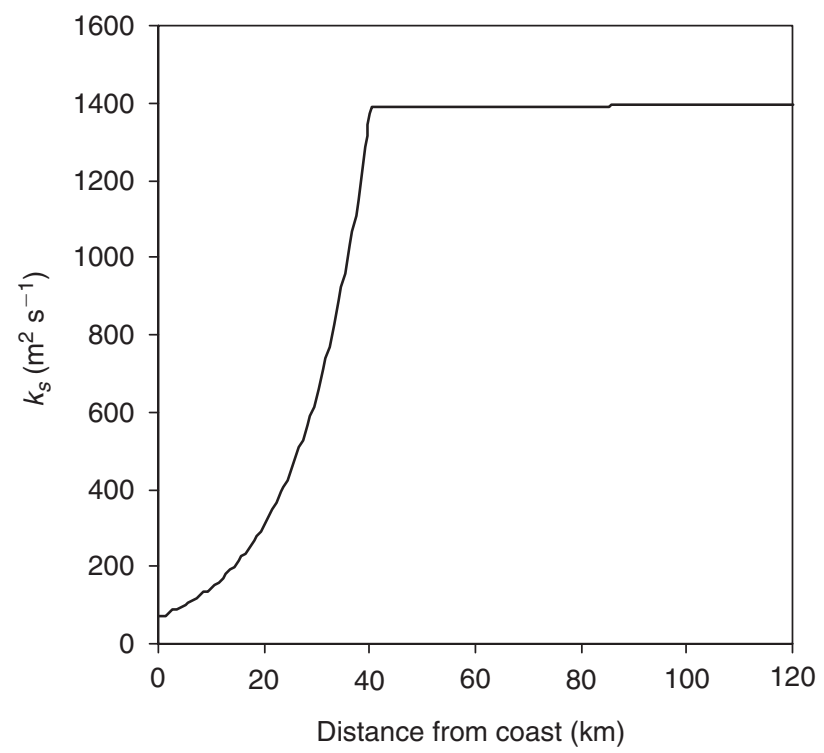

Fig. 9. Diffusion coefficient $v$. distance along the shelf, calculated with $k_{s 1}=1400 \mathrm{~m}^{2} \mathrm{~s}^{-1}, \beta_{1}=0.01 \times 10^{-5} \mathrm{~m}^{-1}, k_{s 2}=1390 \mathrm{~m}^{2} \mathrm{~s}^{-1}$, $\beta_{2}=7.4 \times 10^{-5} \mathrm{~m}^{-1}$, and $x^{\prime}=40 \mathrm{~km}$.

The cross-shelf variation of the calculated diffusion coefficient is shown in Fig. 9. The very small value of $\beta_{1}$ results in a near-constant diffusion coefficient for the offshore part of the lagoon. This corresponds to the portion of the curve in Fig. 8 where the salinity rises slowly at a near-linear rate as the coast is approached. In the offshore $80 \mathrm{~km}$ of the lagoon, salinity increased by $\sim 0.15 \mathrm{ppt}$ only. In contrast, in the inshore $40 \mathrm{~km}$ from the coast, the salinity increased by $0.73 \mathrm{ppt}$.

Equation 12 is an explicit expression that can be used to estimate the diffusion coefficient directly from the salinity data and is a useful check of the numerical procedure described above. From Eqn 12 the diffusion coefficient of the inshore $20 \mathrm{~km}$ is found to be $180 \mathrm{~m}^{2} \mathrm{~s}^{-1}$, very similar to the value shown in Fig. 9. The diffusion coefficient for the offshore $50 \mathrm{~km}$ is calculated to be $2100 \mathrm{~m}^{2} \mathrm{~s}^{-1}$ using Eqn 12, somewhat higher than the value of $1400 \mathrm{~m}^{2} \mathrm{~s}^{-1}$ found using the numerical procedure (see Fig. 9). The large discrepancy for the offshore values is likely to be a result of the very small salinity gradients causing large relative errors in the calculation of Eqn 12, i.e. a small uncertainty in the salinity measurements will cause a large relative error in the salinity gradient.

The diffusion coefficients were calculated only using the equilibrium salinity data, as shown in Fig. 8. A powerful independent check on the validity of the model results can be made by verifying that it also produces the correct timescales for the formation of the hypersaline fringe. Fig. 10 shows the temporal change in the salinity $12 \mathrm{~km}$ from the coast after the initial condition of constant cross-shelf salinity. It can be seen that equilibrium is reached in the order of 50 days, which is in agreement with the results presented in Fig. 4. In Fig. 4, the equilibrium value of salinity is reached around 50 days after the time (Day 250) when salinity is constant across the shelf. In addition, the timescale for the removal of the freshwater from river flooding is also $\sim 50$ days. Walker (1981) also presented data with a

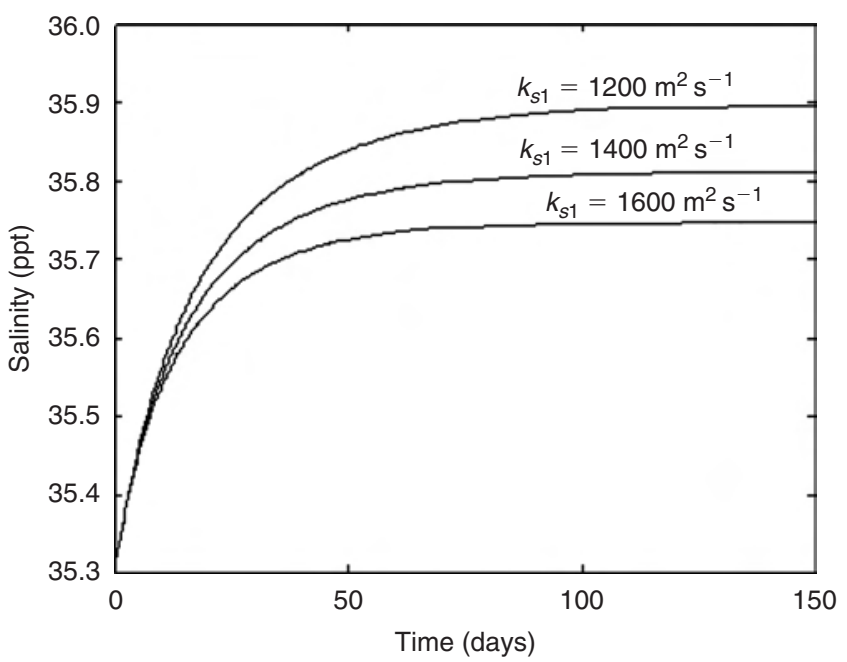

Fig. 10. Calculated salinity (ppt) as a function of time at a position $12 \mathrm{~km}$ from the coast. The initial condition was a constant cross shelf salinity of 35.32. Here, $\beta_{1}=0.01 \times 10^{-5} \mathrm{~m}^{-1}, \beta_{2}=7.4 \times 10^{-5} \mathrm{~m}^{-1}$ and $x^{\prime}=40 \mathrm{~km}$.

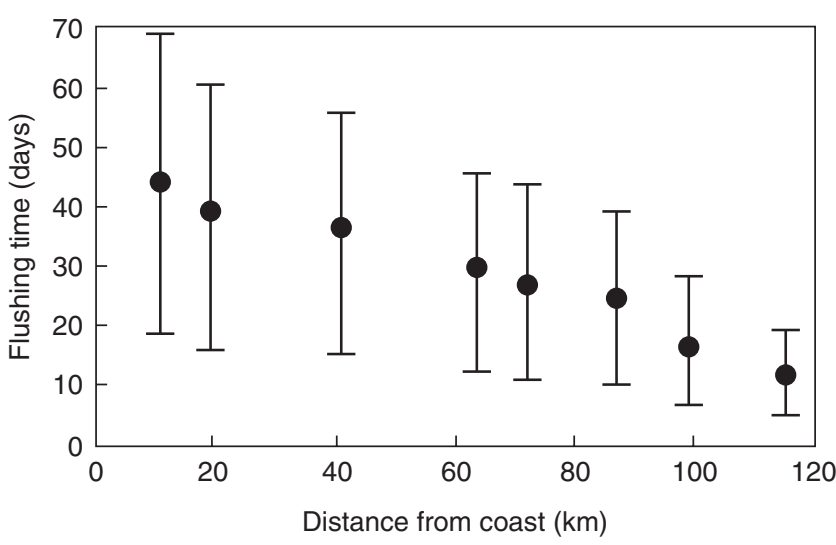

Fig. 11. The flushing times of water at various distances from the coast in the Great Barrier Reef lagoon evaluated using Eqn 2.

timescale for the removal of freshwater of around 2-3 months. Fifty days is a short period compared with the $\sim 200$ daylength of the dry season and hence, the model correctly predicts that cross-shelf equilibrium is easily obtained by the end of the dry season.

\section{Calculating the flushing time for the $G B R$}

The flushing time was calculated using the two methods outlined above i.e. using Eqns 2 and 6.

\section{Flushing time from the exchange model (Eqn 2)}

The flushing time estimate based on the exchange model (Eqn 2) can be evaluated using the field data shown in Fig. 7. The results are shown in Fig. 11. It can be seen that the flushing time for water close to the coast reaches 45 days but decays to 12 days for water near the shelf edge. The magnitude of the error in the calculation is largely associated with the uncertainty in the term $\left(S-S_{c S}\right)$ in 
(a)

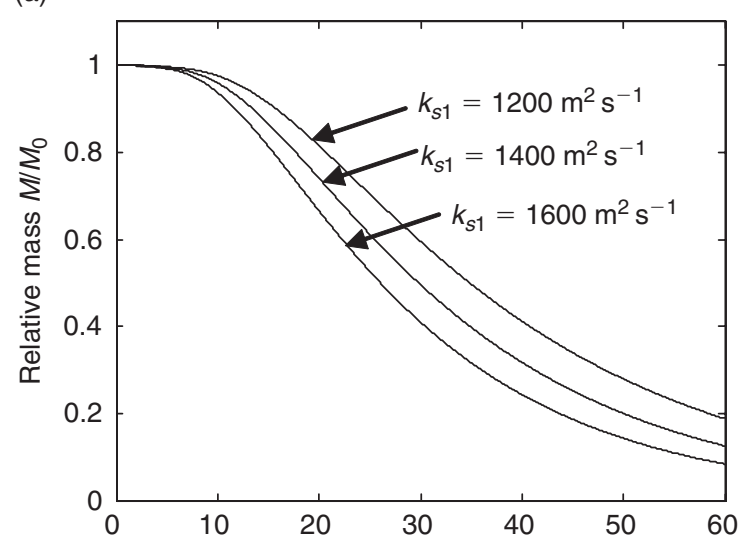

(b)

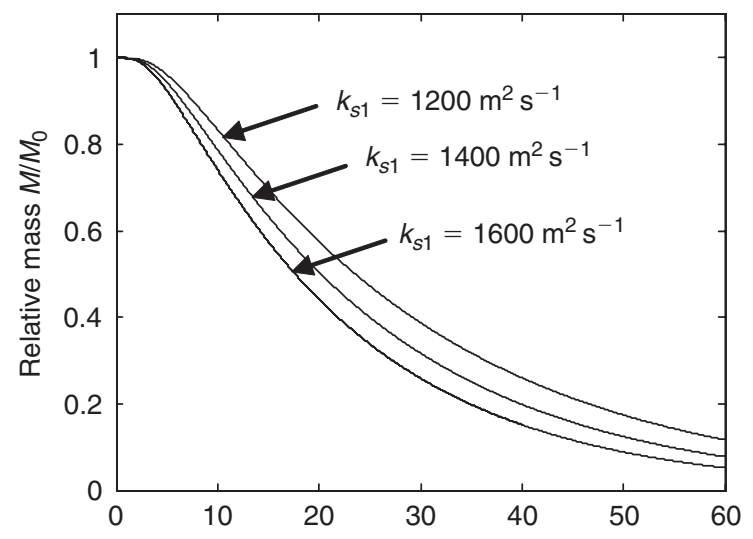

(c)

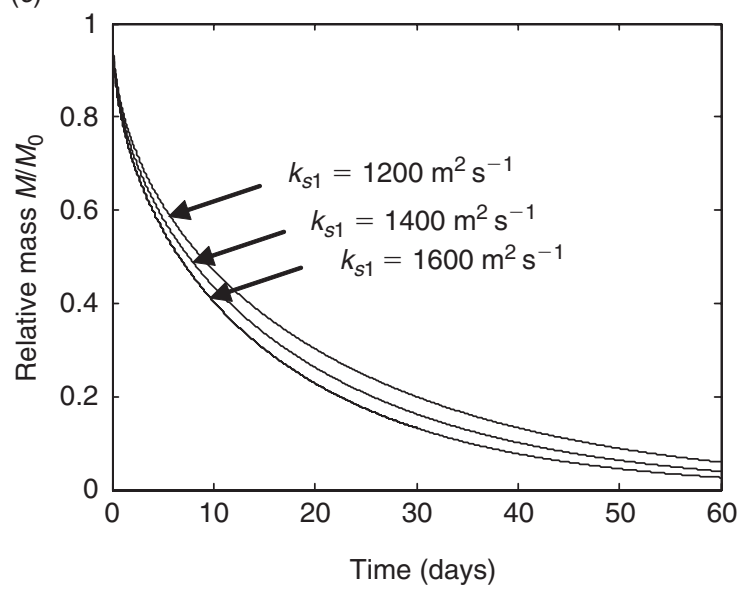

Fig. 12. Relative mass of solute remaining within the lagoon after an initial constant solute concentration within a distance $x^{*}$ from the coast and zero concentration elsewhere. (a) $x^{*}=12 \mathrm{~km}$. (b) $x^{*}=60 \mathrm{~km}$. (c) $x^{*}=120 \mathrm{~km}$ (whole lagoon). Concentration is zero at the offshore boundary. Here $\beta_{1}=0.01 \times 10^{-5} \mathrm{~m}^{-1}, x^{\prime}=40 \mathrm{~km}, k_{s 2}=k_{s 1}-10 \mathrm{~m}^{2} \mathrm{~s}^{-1}$, $\beta_{2}=7.4 \times 10^{-5} \mathrm{~m}^{-1}$.

the numerator of Eqn 2. For example, for the inner shelf typical values $S, S_{c s}$, and $\left(S-S_{c s}\right)$ are $36.1 \pm 0.1 \mathrm{ppt}, 35.4 \pm 0.1 \mathrm{ppt}$ and $0.7 \pm 0.2 \mathrm{ppt}$ respectively. The error in $\left(S-S_{c S}\right)$ is thus $\sim 30 \%$. The relative error in the calculation for the outer reef gets larger
Table 4. Parameters used in Eqn 5 and resulting flushing times of various parts of the lagoon

\begin{tabular}{lll}
\hline Parameters & Locations & Values \\
\hline$k_{s}\left(\mathrm{~m}^{2} \mathrm{~s}^{-1}\right)$ & Shelf-edge $\left(k_{s 1}\right)$ & 1400 \\
$\beta\left(\mathrm{m}^{-1}\right)$ & $40 \mathrm{~km}$ from coast $\left(k_{s 2}\right)$ & 1390 \\
& Shelf-edge & $0.01 \times 10^{-5}$ \\
Flushing time (days) & $40 \mathrm{~km}$ from coast & $7.4 \times 10^{-5}$ \\
& Whole lagoon $(120 \mathrm{~km})$ & $14 \pm 7$ \\
& Water between coast and $60 \mathrm{~km}$ & $28 \pm 12$ \\
& from coast & $38 \pm 16$ \\
& Water between coast and $12 \mathrm{~km}$ & \\
& from coast & \\
\hline
\end{tabular}

owing to the smaller magnitude of $\left(S-S_{c s}\right)$. The other source of significant uncertainty in this calculation is a result of the error in the evaporation rate $E$, which is in the order of $25 \%$.

\section{Flushing time from the diffusion model (Eqn 6)}

The flushing time for a particular region of the lagoon was determined by calculating the mass of material remaining within the lagoon after an initial condition of constant concentration within the region of interest and zero concentration elsewhere. Fig. $12 a$ shows the normalised mass of material $\left(M / M_{0}\right)$ within the lagoon as a function of time after an initial condition of constant concentration within the inshore $12 \mathrm{~km}$ and zero concentration elsewhere. For this initial condition, it can be seen that the solute does not start to be significantly removed from the lagoon until after $\sim 5$ days have elapsed, but is flushed rapidly thereafter. For the $12-\mathrm{km}$ coastal-zone, $\sim 38$ days is required to make the tracer concentration reduce to $1 / e$ at its initial value. Fig. $12 b$ and $c$ are similar to Fig. $12 a$, except the initial conditions are a constant concentration in the inshore $60 \mathrm{~km}$ and $120 \mathrm{~km}$ (the whole lagoon). Flushing times are greatly reduced for these circumstances largely because the diffusion distance is greatly reduced.

The flushing times as defined in Eqn 8 for the various regions and diffusion coefficients are shown in Table 4. It can be seen that the flushing time of the entire lagoon is about 2 weeks, and 1 month for the landward half of the lagoon. For the innermost $12-\mathrm{km}$ coastal zone of the lagoon, the corresponding time is $\sim 38$ days. It should be noted that the waters close to the Coral Sea will have considerable shorter flushing times than the $\sim 2$ weeks calculated for the entire lagoon, as the value for the whole lagoon includes the waters inshore, which have a much larger distance to travel before they reach the Coral Sea.

The results of the diffusion model are consistent with those of the exchange model. For example, the diffusion model gives a flushing time of $38 \pm 16$ days for the inshore $12 \mathrm{~km}$ of the lagoon compared with $45 \pm 25$ days for the exchange model. The uncertainly estimates for these flushing times shown in Table 4 consist of a $25 \%$ uncertainty in the evaporation rate due to the uncertainty in the estimation of the most appropriate value of the diffusion coefficient. From Fig. 12, the uncertainty in the flushing time owing to the uncertainty in the diffusion coefficient 
alone is \pm 3 days, \pm 5 days, and \pm 6 days for material initially within $12 \mathrm{~km}, 60 \mathrm{~km}$ and $120 \mathrm{~km}$ of the coast respectively.

\section{Discussion}

The new salinity data collected specifically for this study combined with the archival salinity data show that during the dry season, hypersaline conditions are spatially and temporally persistent in the dry tropics section of the central GBR lagoon. Water near the coast reaches $\sim 1 \mathrm{ppt}$ higher than the Coral Sea by about October. These results are consistent with the data of Walker (1981, 1982), who also found that in particularly dry years such as 1968 , when little seasonal rainfall occurred, hypersaline conditions may last uninterrupted for $\sim 18$ months. It is notable that the coastal hypersalinity zone reaches equilibrium well before the end of the dry season, a feature also noted in Walker (1981, 1982). This implies that either there is a process that exchanges the hypersaline coastal water with the Coral Sea, or there is a source of fresher water that is advected into the region.

The long-shelf salinity gradient is considerably less than that across the shelf. Fig. $7 a$ highlights that in the inshore $20-\mathrm{km}$ region, the salinity varies by around $0.2 \mathrm{ppt}$ along the $180 \mathrm{~km}$ of coast, but with no consistent trend of increasing or decreasing salinity along the coast. A similar variation of $0.2 \mathrm{ppt}$ occurs in the cross-shelf direction in a distance of less than $10 \mathrm{~km}$ within the inshore $20-\mathrm{km}$ zone. The cross-shelf salinity variation also shows a relatively consistent falling salinity with distance from the coast. The magnitude of the cross-shelf salinity gradient is thus $2 \times 10^{-5} \mathrm{ppt} \mathrm{m}^{-1}$. The magnitude of the long-shore gradient is in the range 0 to $10^{-6} \mathrm{ppt} \mathrm{m}^{-1}$, i.e. the cross-shelf gradients are at least an order of magnitude greater than the long-shore gradients.

Higher cross-shelf gradients are also evident further from the coast. In the offshore $50 \mathrm{~km}$, the long-shore salinity varies by less than $0.05 \mathrm{ppt}$ over $180 \mathrm{~km}$ and the cross-shelf salinity varies by $\sim 0.1 \mathrm{ppt}$ over $50 \mathrm{~km}$. The magnitude of the cross-shelf salinity gradient is thus $2 \times 10^{-6} \mathrm{ppt} \mathrm{m}^{-1}$ and the magnitude of the long-shore gradient is in the range 0 to $3 \times 10^{-7} \mathrm{ppt} \mathrm{m}^{-1}$. It is thus evident that the long-shelf salinity gradients are at least five times less than the cross-shelf salinity gradients.

Together with the information regarding long-shore currents in Table 1, the data of the along-shore salinity gradient can be used to determine if the $1 \mathrm{D}$ diffusion model is valid, i.e. can long-shore advective processes be ignored. It is not obvious that a simple 1D cross-shelf model can be used to determine cross-shelf transport of the GBR lagoon where the cross-shelf dimension is over an order of magnitude less than the long-shelf dimension.

In order to justify the 1D assumption, it is necessary to show that any changes in salinity associated with the advection of an along-shore salinity gradient by an along-shore current are small compared with the evaporative forcing term in Eqn 6, i.e.

$$
\frac{\partial S}{\partial t}=\frac{E S}{h}
$$

All other terms in Eqn 6 reduce the increase in salt concentration generated by the evaporation forcing term above. Typical values of this term are $4 \times 10^{-7} \mathrm{ppts}^{-1}, 2 \times 10^{-7} \mathrm{ppts}^{-1}$, $8 \times 10^{-8} \mathrm{ppts}^{-1}$ and $4 \times 10^{-8} \mathrm{ppts}^{-1}$ at water depths of $5 \mathrm{~m}$,
$10 \mathrm{~m}, 25 \mathrm{~m}$, and $50 \mathrm{~m}$ respectively. In the absence of some exchange process, the salinity would rise over the 6 months of dry season by $6,3,1$ and $0.6 \mathrm{ppt}$ at water depths of $5 \mathrm{~m}, 10 \mathrm{~m}$, $25 \mathrm{~m}$, and $50 \mathrm{~m}$ respectively.

Long-shore advection will cause a rate of concentration change given by

$$
\frac{\partial S}{\partial t}=v \frac{\partial S}{\partial y}
$$

where $v$ is the long-shore current and $y$ is the long-shelf direction. As mentioned above, the long-shore salinity gradient was difficult to measure because it was small and had no consistent direction along the $180-\mathrm{km}$ section of the lagoon where measurements were taken. The magnitude of the long-shore salt concentration gradient is in the range 0 to $10^{-6} \mathrm{ppt} \mathrm{m}^{-1}$ inshore, and in the range 0 to $3 \times 10^{-7} \mathrm{ppt} \mathrm{m}^{-1}$ offshore. Assuming a long-shore current of $5 \mathrm{~cm} \mathrm{~s}^{-1}$, this will produce a rate of change of salt concentration in the range 0 to $5 \times 10^{-8} \mathrm{ppt} \mathrm{s}^{-1}$ inshore and in the range 0 to $1.5 \times 10^{-8} \mathrm{ppts}^{-1}$ offshore. The inshore values are an order of magnitude lower than those calculated using Eqn 12 and thus it can be concluded that long-shore fluxes cannot account for the observed equilibrium values of inshore salt concentrations, i.e. long-shore fluxes cannot negate the effect of evaporation in increasing salt concentrations. On the other hand, near the shelf break, long-shore fluxes may cause up to a $1.5 \times 10^{-8} \mathrm{ppts}^{-1}$ reduction in salt concentration that is a significant fraction of the $8 \times 10^{-8} \mathrm{ppt} \mathrm{s}^{-1}$ increase as calculated from Eqn 12. More measurements are thus required in order to fully evaluate the contribution of long-shore advection on salt concentrations in the offshore areas.

Another process, which may prevent the evaporation-driven rise in salinity, could be direct groundwater flow to the ocean. Little work has been done on groundwater flow to the GBR but Stieglitz (2005) has documented direct groundwater flow to near-shore waters from coastal wetlands and sand dune areas. These flows produce a narrow fringe of low salinity water close to the coast and so far have only been documented in the wet tropics area well to the north of the area of interest in this work. However, in the dry tropics area of the Burdekin delta evidence indicates that landward directed groundwater incursion of salt tongues have occurred, suggesting that seaward-groundwater flows are not affecting coastal waters.

There is also a possibility that fresxhwater discharge exists in deeper areas of the shelf. There is circumstantial evidence that freshwater springs known locally as 'Wonky Holes' are intermittent freshwater springs that occur primarily north of the area of interest in this paper (Stieglitz 2005). Studies of these features indicate that they occur in regions where a coastally attached sediment wedge overlays ancient river channels on the shelf and may still be connected hydraulically to the coastal plains (Stieglitz 2005). Measurement of salinity over the 'Wonky Holes' indicate that if Wonky Holes are springs, they certainly do not produce large quantities of fresh water (if any) in periods of dry weather (T. Stieglitz and P. Ridd, James Cook University, unpubl. data). They therefore probably do not contribute large volumes of water to the lagoon in the late dry season, or in years when there is minimal wet season rain. Additionally, very few 'Wonky Holes' are documented in the Townsville region except 
in the extreme north of the region considered in this work, i.e. north of transect V.

Diffusion coefficients calculated from this work are generally higher than those found by Hancock et al. (2006). Calculations based on the more recent salinity data indicate an even higher diffusion coefficient rising to up to $1400 \mathrm{~m}^{2} \mathrm{~s}^{-1}$ on the shelf break. Despite the difference in the results, both this work and that of Hancock et al. (2006) indicate that flushing times for the lagoon are relatively short.

The salinity data discussed in this work do not appear to support the conclusions of Luick et al. (2007), who found that water remains close to the coast for extended periods. It is difficult to reconcile the limited buildup in measured coastal salt concentration that is observed close to the coast with the observed tracks of Lagrangian drifters that crossed the shelf slowly to the Coral Sea (Luick et al. 2007).

The large values of the diffusion coefficient calculated in this paper not only correctly predict the magnitude of the coastal hypersalinity fringe, they also predict the timescale of formation of the hypersaline conditions, i.e. a few months. This serves as a powerful independent check of the results as the diffusion coefficients were calculated only on the equilibrium data. If smaller diffusion coefficients were used, the time scales for the formation of the hypersaline fringe would be larger than those observed.

\section{Conclusions}

The salinities close to the coast of the dry tropics section of the central GBR lagoon are persistently elevated above the normal seawater value due to evaporation at the end of the dry season. The magnitude of the coastal hypersalinity is controlled by the degree of mixing with water from the Coral Sea (i.e. the crossshelf diffusion coefficient). Salinity data show that typical depthaveraged salinity at the coast is $\sim 0.48 \mathrm{ppt}$ higher than the water $15 \mathrm{~km}$ from the coast and $0.75 \mathrm{ppt}$ higher than the water $40 \mathrm{~km}$ from the coast. At the same time, the salinity gradient along shelf is much less than the cross-shelf gradient. In the alongshelf distance of $\sim 180 \mathrm{~km}$ from the south transect I to the north transect $\mathrm{V}$, the depth-averaged salinity changes by only $\sim 0.2 \mathrm{ppt}$. The cross-shelf salinity gradient is thus an order of magnitude greater than the along-shelf gradient. Calculations indicate that long-shelf advective fluxes are not significant in determining the long-shelf averaged salinities for the inner and mid-shelf, but may be important on the shelf break. More data are required to clarify the situation on the shelf break. Nevertheless, the data indicate that the use of a one-dimensional (cross-shelf) diffusion model is valid for the dry season conditions assumed in the model, if one is considering long-shelf averages of salinity.

By using in situ salinity as a tracer, a diffusion model of the shelf-exchange processes was developed. In this diffusion model, the diffusion coefficients of the lagoon have been determined. It was found that the offshore two-thirds of the shelf required a very high and almost constant diffusion coefficient of $\sim 1400 \mathrm{~m}^{2} \mathrm{~s}^{-1}$. In addition, the diffusion coefficient for the inshore third of the shelf decreased rapidly from $1400 \mathrm{~m}^{2} \mathrm{~s}^{-1}$ at $40 \mathrm{~km}$ from the coast to $70 \mathrm{~m}^{2} \mathrm{~s}^{-1}$ at the coast. The reason for the very large diffusion coefficient offshore is possibly the existence of large-scale turbulence generated by flow around reefs.
The inshore section of the lagoon is almost devoid of reefs and thus a smaller diffusion coefficient is expected.

Once the diffusion coefficients were determined, the flushing time of the lagoon was calculated and compared with the results of a simple exchange model that also used salinity as a passive tracer. This exchange model makes no assumptions about the processes that occur in the lagoon, and there is no intermediate step of determining the diffusion coefficient to calculate the flushing time. The exchange model yielded consistent results with the diffusion model, i.e. the flushing time of $45 \pm 25$ days and $38 \pm 16$ days for the inshore $10 \mathrm{~km}$ of the lagoon for the exchange and diffusion models respectively.

The flushing times calculated in this paper indicate that inshore waters are flushed with water from the Coral Sea over 1 or 2 months, whereas offshore water requires only a few weeks to be flushed. It is thus evident that very large volumes of water in the central lagoon are exchanged with the Coral Sea on time scales of weeks to months.

\section{Acknowledgements}

This study was supported by the Australian Research Council Discovery Grant DP0558516. Financial support was also given by National Natural Science Foundation of China grant 40406015. Martial Depczynski, Chris Fulton, and James Whinney helped with the collection of the salinity data. Severine Thomas and three anonymous reviewers greatly helped improve this manuscript.

\section{References}

Andrews, J. C. (1983). Water masses, nutrient levels and seasonal drift on the outer central Queensland shelf (Great Barrier Reef). Marine and Freshwater Research 34, 821-834. doi:10.1071/MF9830821

Anthony, K. R. N. (2000). Enhanced particle-feeding capacity of corals on turbid reefs (Great Barrier Reef, Australia). Coral Reefs 19, 59-67. doi: $10.1007 / \mathrm{S} 003380050227$

Baker, J. T. (2003). A report on the study of land-sourced pollutants and impacts on water quality in and adjacent to the Great Barrier Reef. Intergovernmental Steering Committee, GBR Water Quality Action Plan, Premier's Department, Queensland Government, Brisbane.

Brinkman, R., Wolanski, E. J., Deleersnijder, E., McAllister, F., and Skirving, W. J. (2002). Oceanic inflow from the Coral Sea into the Great Barrier Reef. Estuarine, Coastal and Shelf Science 54, 655-668. doi:10.1006/ ECSS.2001.0850

Burling, M. C., Ivey, G. N., and Pattiaratch, C. B. (1999). Convectively driven exchange in a shallow coastal embayment. Continental Shelf Research 19, 1599-1616. doi:10.1016/S0278-4343(99)00034-5

Burrage, D. M., Church, J. A., and Steinberg, C. R. (1991). Linear systems analysis of momentum on the continental shelf and slope of the Central Great Barrier Reef. Journal of Physical Oceanography 96, 169-190.

Carter, R. M. C. (2006). Great news for the Great Barrier Reef: Tully River water quality. Energy \& Environment 17, 527-548. doi:10.1260/ 095830506778644233

Choi, K. W., and Lee, J. H. W. (2004). Numerical determination of flushing time for stratified water bodies. Journal of Marine Systems 50, 263-281. doi:10.1016/J.JMARSYS.2004.04.005

Das, P., Marchesiello, P., and Middleton, J. H. (2000). Numerical modelling of tide-induced residual circulation in Sydney Harbour. Marine and Freshwater Research 51, 97-112. doi:10.1071/MF97177

da Silva, A., Young, A. C., and Levitus, S. (1994). 'Atlas of Surface Marine Data 1994, Volume 1: Algorithms and Procedures.' NOAA Atlas NESDros. Inf. Serv. 6. (US Department of Commerce: Washington, DC.) 
Fischer, H. B., List, E. J., Koh, R. C.Y., Imberger, J., and Brooks, N. H. (1979) 'Mixing in Inland and Coastal Waters.' (Academic Press: London.)

Furnas, M. (2003). 'Catchments and Corals: Terrestrial Runoff to the Great Barrier Reef.' (Australian Institute of Marine Science and CRC Reef Research Centre: Townsville, Australia.)

Geyer, W. R., Morris, J. T., Pahl, F. G., and Jay, D. A. (2000). Interaction between physical processes and ecosystem structure: a comparative approach. In 'A Synthetic Approach to Research and Practice'. (Ed. J. E. Hobbie.) pp. 177-206. (Island Press: Washington, DC.)

Gibson, J. K., Kallberg, P., Uppaa, S., Hernandez, A., Nomura, A., and Serrano, E. (1997). ECMWF Re-analysis project, 1. ERA description, Project Report Series, European Center for Medium range Weather Forecasting (ECMWF) report, July 1997.

Hancock, G. J., Webster, I. T., and Stieglitz, T. C. (2006). Horizontal mixing of Great Barrier Reef waters: offshore diffusivity determined from radium isotope distribution. Journal of Geophysical Research 111, C12019. doi:10.1029/2006JC003608

Haynes, D., Ralph, P., Prange, J., and Dennison, W. (2000a). The impact of the herbicide diuron on photosynthesis in three species of tropical seagrass. Marine Pollution Bulletin 41, 288-293. doi:10.1016/S0025 326X(00)00127-2

Haynes, D., Müller, J., and Carter, S. (2000b). Pesticide and herbicide residues in sediments and seagrasses from the Great Barrier Reef World Heritage Area and Queensland Coast. Marine Pollution Bulletin 41 , 279-287. doi:10.1016/S0025-326X(00)00097-7

Hoegh-Guldberg, O. (1999). Climate change, coral bleaching and the future of the worlds's coral reefs. Marine and Freshwater Research 50, 839866. doi:10.1071/MF99078

Josey, S. A., Kent, E. C., and Taylor, P. K. (1998). The Southampton Oceanography Centre (SOC) Ocean-Atmosphere Heat, Momentum and Freshwater Flux Atlas. Southampton Oceanography Centre Report 6, Southampton, UK. Available online at: http://www.soc.soton.ac.uk/JRD/MET/ PDF/soc-flux-atlas.pdf (verified August 2007).

Kalnay, E., Kanamistu, M., Kistler, R., Collins, W., Deaven, D., Gandin, L., \& Iredell, M., et al. (1996). The NCEP/NCAR reanalysis project Bulletin of the American Meteorological Society 77, 437-471. doi:10.1175/15200477(1996)077<0437:TNYRP> 2.0.CO;2

Luick, J., Mason, L., Hardy, T., and Furnas, M. J. (2007). Circulation in the Great Barrier Reef Lagoon using numerical tracers and in situ data. Continental Shelf Research 27, 757-778. doi:10.1016/J.CSR.2006.11.020

Macdonald, I. A., Perry, C. T., and Larcombe, P. (2005). Comment on 'Rivers, runoff, and reefs' by MacLaughlin et al. Global and Planetary Change 45, 333-337 [Global and Planetary Change 39 (2003) 191-199]. doi:10.1016/J.GLOPLACHA.2004.11.001

Monsen, N. E., Cloern, J. E., Lucas, L. V., and Monismith, S. G. (2002). A comment on the use of flushing time, residence time, and age as transport time scales. Limnology and Oceanography 47, 1545-1553.

Neil, D. T., Orpin, A. R., Ridd, P. V., and Yu, B. (2002). Sediment yield and impacts from river catchments to the Great Barrier Reef lagoon. Marine and Freshwater Research 53, 733-752. doi:10.1071/MF00151
Nunes, R. A., and Lennon, G. W. (1986). Physical property distribution and seasonal trends in Spencer Gulf, South Australia: an in verse estuary. Marine and Freshwater Research 37, 39-53. doi:10.1071/ MF9860039

Prandle, D. (1984). A modeling study of the mixing of ${ }^{137} \mathrm{Cs}$ in the seas of the European continental shelf. Philosophical Transactions of the Royal Society of London. Series A: Mathematical and Physical Sciences 310, 407-436. doi:10.1098/RSTA.1984.0002

Ridd, P. V., and Stieglitz, T. C. (2002). Dry season salinity changes in arid estuaries fringed by mangroves and saltflats. Estuarine, Coastal and Shelf Science 54, 1039-1049. doi:10.1006/ECSS.2001.0876

Schaffelke, B., Mellors, J., and Duke, N. C. (2005). Water quality in the Great Barrier Reef region: responses of mangrove, seagrass and macroalgal communities. Marine Pollution Bulletin 51(1-4), 279-296. doi:10.1016/J.MARPOLBUL.2004.10.025

Stieglitz, T. (2005). Submarine groundwater discharge into the near-shore zone of the Great Barrier Reef, Australia. Marine Pollution Bulletin 51, 51-59. doi:10.1016/J.MARPOLBUL.2004.10.055

Taylor, G. I. (1954). The Dispersion of matter in turbulent flow through a pipe. Proceedings of the Royal Society of London. Series A 223, 446-468

Walker, T. (1981). Seasonal salinity variations in Cleveland Bay, Northern Queensland. Australian Journal of Marine and Freshwater Research 32, 143-149. doi:10.1071/MF9810143

Walker, T. (1982). Lack of evidence for evaporation-driven circulation in the Great Barrier Reef Lagoon Australian Journal of Marine and Freshwater Research 33, 717-722. doi:10.1071/MF9820717

Wolanski, E., and Jones, M. (1979). Biological, chemical and physical observations in inshore waters of the the Great Barrier Reef, North Queensland, 1979. Australian Institute of Marine Science, Data Report, Oceanography Series No.2.

Wolanski, E., and Jones, M. (1981). Physical properties of Great Barrier Reef Lagoon Waters near Townsville. I. Effects of Burdekin River floods. Australian Journal of Marine and Freshwater Research 32, 305-319. doi:10.1071/MF9810305

Wolanski, E., and Pickard, G. L. (1985). Long-term observations of currents on the central Great Barrier Reef continental shelf. Coral Reefs 4, 47-57. doi:10.1007/BF00302205

Wolanski, E., Asaeda, T., Tanaka, A., and Deleersnijder, E. (1996). Three-dimensional island wakes in the field, laboratory and numerical models. Continental Shelf Research 16, 1437-1452. doi:10.1016/02784343(95)00087-9

Wolanski, E., Richmond, R., McCook, L., and Sweatman, H. (2003). Mud, marine snow and coral reefs. American Scientist 91, 44-51. doi:10.1511/2003.1.44

Manuscript received 16 August 2006, accepted 30 July 2007 